J. Clin. Chem. Clin. Biochem.

Vol. 15, 1977, pp. 393-396

\title{
Whole Salivary Immunoglobulin Levels in 60 Healthy Children: Determined by a Sensitive Electroimmuno Technique after Prior Carbamylation
}

\author{
By P. A. Ostergaard and M. Blom
}

Department of Clinical Chemistry, Aalborg Hospital South, DK-9000 Aalborg, Denmark

(Received December 30,1976)

Summary: Immunoglobulins in whole saliva, collected unstimulated from 60 healthy children, 4 to 15 years of age, were determined by a modified electroimmuno technique using carbamylation of the samples prior to electrophoresis. This technique, which is generally used for measurement of immunoglobulins in serum, was found to be rapid, precise, and sensitive. The mean (median) for salivary IgA was $5.1 \mathrm{kIU} / 1$, which was significantly higher than values obtained from stimulated or unstimulated parotid saliva by other investigators. The mean value for salivary IgG was $120 \mathrm{IU} / 1$. IgM in saliva was only found in measurable amounts in 5 children.

\section{Immunoglobulin-Konzentrationen im Gesamt-Speichel bei 60 gesunden Kindern: Bestimmung mit einer empfindlichen Elektro-Immun-Technik nach vorheriger Carbamylierung}

Zusammenfassung: Die Immunglobuline im Gesamt-Speichel, der ohne Stimulation von 60 gesunden, 4-15 Jahre alten Kindern gewonnen wurde, wurden mit einer modifizierten Elektro-Immun-Technik nach Carbamylierung der Proben vor der Elektrophorese bestimmt. Diese Technik, die hauptsächlich für die Bestimmung der Immunglobuline im Serum angewandt wird, erwies sich als schnell, genau und empfindlich. Der Mittelwert (median) für IgA im Speichel war mit $5,1 \mathrm{kIU} / 1$ signifikant höher als von anderen Untersuchern in Parotis-Speichel mit und ohne Stimulierung gefundene Werte. Der Mittelwert für IgG im Speichel betrug 120 IU/l. IgM wurde in meßbaren Mengen nur im Speichel von 5 Kindern gefunden.

\section{Introduction}

Most of the methods published for immunoglobulin estimations in secretions are based upon immunodiffusion methods. During investigations in children with severe respiratory infections in connection with low IgA levels in serum, we looked for a method to quantitate the three classes of immunoglobulins, IgG, IgA and IgM, in unconcentrated saliva. A method for that purpose should be rapid, highly sensitive, and sufficiently precise in the daily routine. Recently, Khayam-Bashi et al.:(1) presented a single radial immunodiffusion method with a sensitivity for the estimation of salivary IgA of $95 \mathrm{mg} / 1$. However, we found that a modified electroimmuno technique, originally developed by Weeke $(2,3)$ for immunoglobulin estimation in serum, was able to measure salivary IgA in saliva in concentration as low ạ 7.7 $\mathrm{mg} / \mathrm{l}$. This method exploits the ability of cyanates to decrease the isoelectric points, and gives rise to high precipitates migrating only in the anodical direction in the antibody-containing gels. The present paper reports an optimized procedure and reference values for immunoglobulins in saliva from 60 healthy children.

\section{Material and Methods}

\section{Probands}

Saliva was obtained from 60 children, 4 to 15 years of age. All the children were healthy school or preschool children, who had never been admitted to hospital. They had never experienced atopic diseases or severe, respiratory infections. All of the children (or their parents) were individually interviewed by a medical practitioner concerning health, and the throat was inspected to safeguard that the tonsils were in situ and offered no signs of chronic infections.

The children were divided into 4 age groups:

1.15 children, 4 to 6 years of age,

2. 12 children, 7 to 9 years of age,

3. 15 children, 10 to 12 years of age, and

4. 18 children, 13 to 15 years of age.

The ratio boys: girls was nearly unity, $28: 32$. 


\section{Collection of saliva}

Saliva was sucked directly from the floor of the mouth without stimulation of salivary flow rate and at least one hour after a meal. The equipment used consisted of a glass test tube provided with a plastic cap and 2 syringes (Rekord $1.1 \times 30 \mathrm{~mm}$ ) and 2 plastic rubbers with an external diameter of $3 \mathrm{~mm}$, one of them being connected to a suction pump; the other was used directly for suction of the saliva. Suction on the system provoked a negative pressure in the test tube, sufficiently to collect saliva from the mouth without exerting an appreciable stimulation of salivary flow rate. About one ml of saliva was collected and stored immediately at $-20^{\circ} \mathrm{C}$ until immunoglobin determination. After the saliva had been thawed, mucous debris had sedimented in most samples, leaving a clear supernatant. Only a few saliva samples needed gentle centrifugation for sedimentation of the debris. The samples were always tested with Haemastix for blood contamination and found negative. None of the children offered signs of inflammatory processes of the mouth.

Preparation of standards and samples

Pooled human serum, calibrated in terms of the WHO Immunoglobulin Reference Preparation (67/97), was used as a working standard. This pool was stored at $-20^{\circ} \mathrm{C}$ and diluted prior to carbamylation because the concentrations of immunoglobulins expected in saliva were much lower. 4 or 5 standards in the range of 90-790 IU/1 for IgG, 540-3550 IU/I for IgA, and 2.04-10.67 $\mathrm{kIU} / \mathrm{l}$ for IgM were included in each run. The saliva specimens were used undiluted or diluted 1:2 with buffer.

Carbamylation of the standards and samples

The standard solutions and the samples were allowed to react with equal amounts of $1.0 \mathrm{~mol} / \mathrm{l}$ potassium cyanate (Merck Schuchardt, D-6100 Darmstadt cat. no. 804957) for 75 minutes at $37^{\circ} \mathrm{C}$. The specimens were exposed to electrophoresis either immediately or up to one hour after carbamylation, being kept in an ice-water bath.

Preparation of the gels

For each run, a mould was made of two glass plates $(205 \times 110 \times 1.5 \mathrm{~mm})$, one of which was coated with $5 \mathrm{~g} / \mathrm{l}$ agarose gel, and a U-frame with a thickness of $1 \mathrm{~mm}$ (Dansk Laboratorieudstyr A/S, Copenhagen, Denmark, cat. no. 4400). Appropriate amounts of specific antisera were added to $22 \mathrm{ml}$ $10 \mathrm{~g} / \mathrm{l}$ agarose gel (L'Industrie Biologique Française S. A. Gennevilliers, France, cat. no. F. 8749, batch A 37), dissolved in barbital buffer, $\mathrm{pH} 8.6$, ionic strength 0.075 and containing calcium lactate $0.58 \mathrm{~g} / 1$ at $50^{\circ} \mathrm{C}$. These amounts of monospecific antisera, raised in rabbits against purified human serum
IgG, IgM and colostrum IgA, were 60,70 , and $80 \mu \mathrm{l}$ respectively. The antisera were obtained from a commercial source (Dakopatts A/S, Hellerup, Denmark, 10-090, 10-091, and 10-MAT).

After solidification of the gel, the uncoated glass plate was gently removed, and wells with a diameter of $4 \mathrm{~mm}$ were punched out using a template and a gel puncher (3).

\section{Electrophoresis}

After application of the carbamylated standard dilutions and samples (sample volume $7 \mu \mathrm{l}$ ), the glass plate with the gel was placed on the electrophoresis apparatus (Dansk Laboratorieudstyr A/S, Copenhagen, Cat. no. 0110).

The gel was connected by cotton wicks to the buffer vessels with the barbital buffer, which was also used for the preparation of the gel. Electrophoresis was carried out with $75 \mathrm{~V}$ on the power supply for 16 hours. The cooling was performed with a recirculating system, thermostated at 12 to $14{ }^{\circ} \mathrm{C}$.

After electrophoresis, the plates were pressed and dried; the immunoprecipitates were stained with Coomassie Brilliant Blue $\mathrm{R}-250$ and the background destained as specified by Weeke (4).

\section{Results}

Figure 1 shows immunoprecipitates ('rockets') from an IgA plate after staining. In every individual run, a control serum, diluted to immunoglobulin concentrations within the range of the respective calibration curves, was included. The coefficients of variation (day-to-day) during twenty days were $7.1,5.6$, and $5.4 \%$ for $\operatorname{IgG}$, IgA, and IgM respectively.

Immunoglobulin determination in saliva Mean (the median) saliva IgA in all the children was 5.1 $\mathrm{kJU} / 1$ with 5 and 95 per cent percentiles of 2.7 to 9.7 $\mathrm{kIU} / 1$. The individual values obtained in the different age groups appear in figure 2 . The 90 per cent range of the observations in the 4 to 6 year old age group was 2.7 to $6.7 \mathrm{kIU} / 1$ with a mean of $4.2 \mathrm{kIU} / 1$. In the 7 to 9 years age group, a mean salivary IgA of $4.6 \mathrm{kIU} / 1$ was

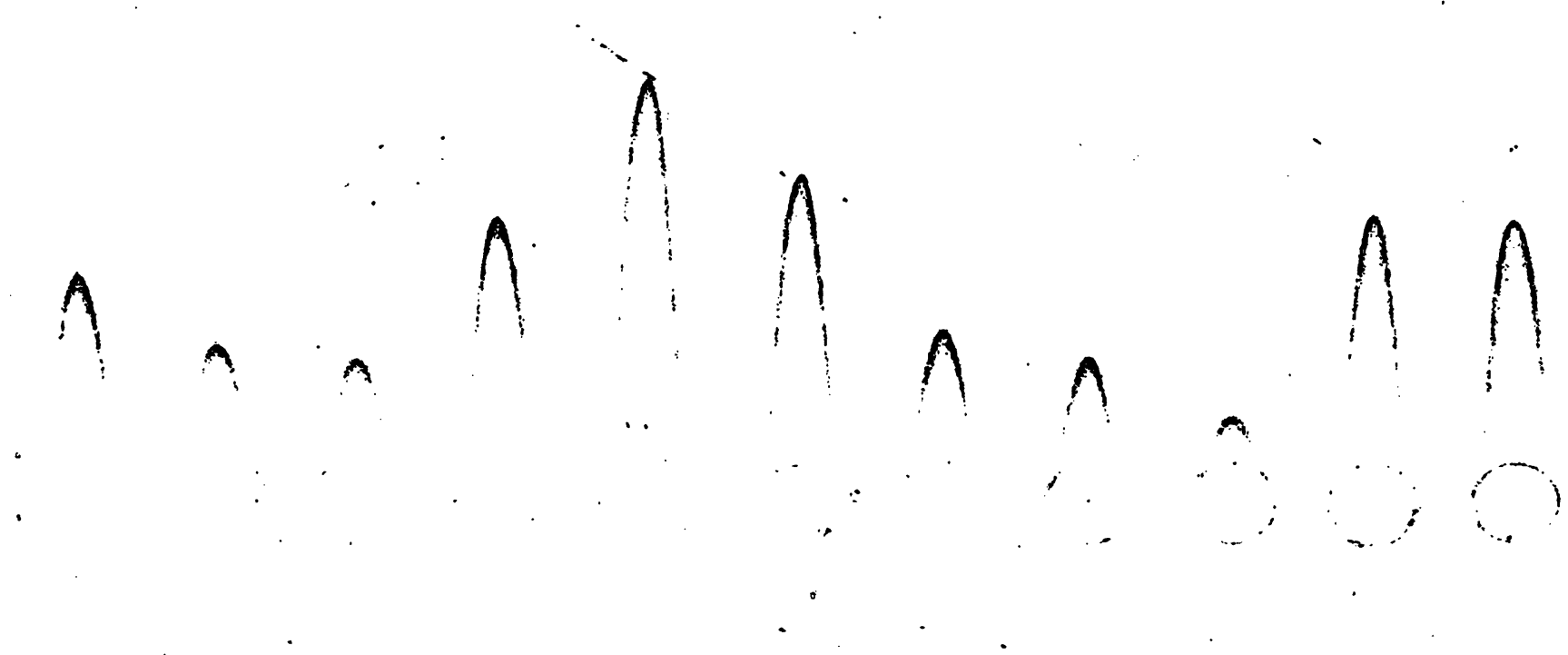

Fig. 1. Immunoprecipitates ('rockets') from an IgA plate stained with Coomassie Brilliant Blue. Standard dilutions and saliva specimenns. 


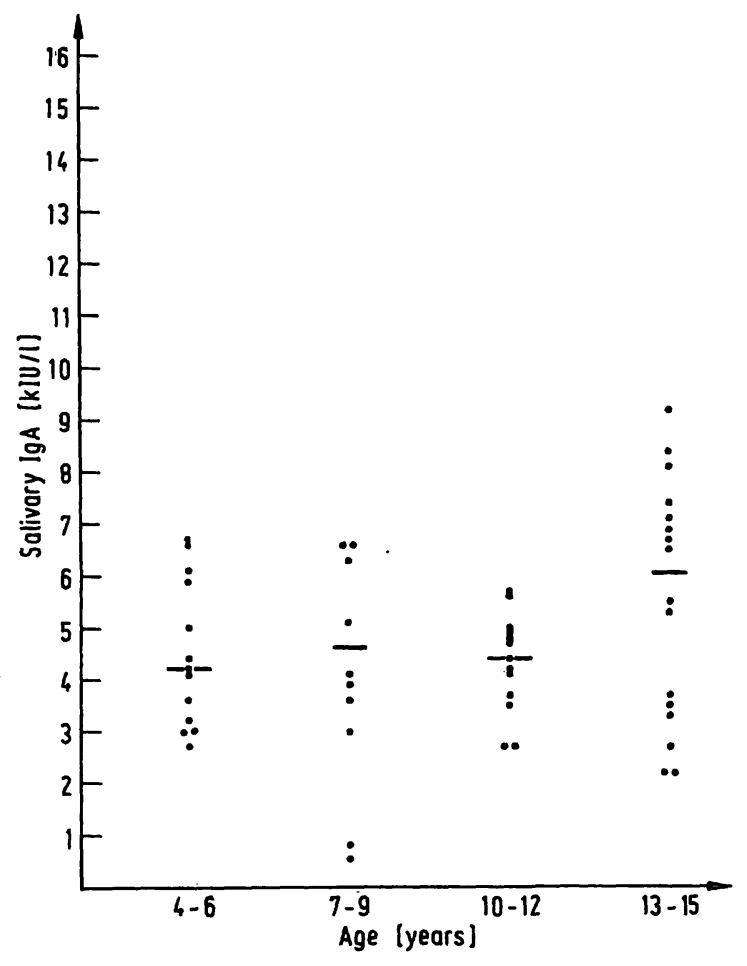

Fig. 2. Salivary IgA values obtained in the different age groups. Medians and 90 per cent ranges.

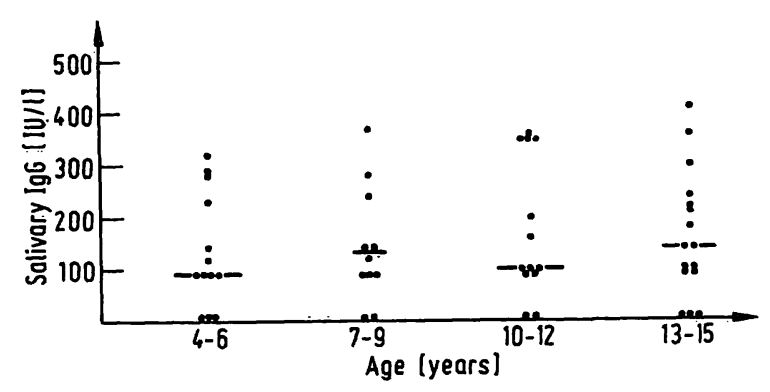

Fig. 3. Salivary IgG values obtained in the different age groups. Medians and 90 per cent ranges.

found with a rather wide 90 per cent range of 0.54 to $16.4 \mathrm{kIU} / \mathrm{l}$. In the 10 to 12 year age group, a mean salivary IgA of $4.4 \mathrm{kIIU} / 1$ was found with a 90 per cent range of 2.7 to $5.7 \mathrm{kIU} / \mathrm{l}$. In the 13 to 15 year age group, a mean salivariry IgA of $6.0 \mathrm{kIU} / 1$ with a 90 per cent range of 2.2 to $9.2 \mathrm{kIU} / \mathrm{l}$ was found.

Salivary IgG was detected in 47 of the 60 children concerned. Mean salivary IgG in all the children was $120 \mathrm{IU} / 1$ with a 90 per cent range of 0 to $410 \mathrm{IU} / 1$. The results of the salivary IgG estimations appear in figure 3. Mean salivary IgG of the 4 to 6 year old children was $90 \mathrm{IU} / 1$ with a 90 per cent range of 0 to $320 \mathrm{IU} / 1$. In the age group 7 to 9 years, a mean salivary IgG of $130 \mathrm{IU} / \mathrm{l}$ and a 90 per cent range of 0 to $370 \mathrm{IU} / 1$ was found. In the 10 to 12 year age group, the mean salivary IgG was $100 \mathrm{IU} / \mathrm{l}$, and the 90 per cent range of the observations was 0 to $360 \mathrm{IU} / 1$. Finally, a mean salivary IgG of $140 \mathrm{IU} / 1$ with a 90 per cent range of 0 to $410 \mathrm{IU} / 1$ was found in the age group 13 to 15 years.
Salivary IgM was only found in 5 children in measurable amounts, and in 6 children trace amounts were detected (visible precipitates lower than that of the most diluted standard).

Statistical evaluation of the results of salivary $\operatorname{IgG}$ and IgA in the four age groups, determined by the MannWhitney $\mathrm{U}$ test, showed no differences between the individual age groups $(p>0.05)$.

\section{Discussion}

As shown by Weeke $(2,3)$, the reaction between potassium cyanate and free $\alpha$-and $\epsilon$-amino and sulfhydryl groups of proteins can be exploited in the determination of immunoglobulins in serum. The reaction decreases the isoelectric points and thus increases the electrophoretic mobility of these antigens. At pH 8.6 only anodical immuno-precipitates are formed. The same author has shown that cyanate somehow interfers with the ability of the antigens to combine with antibodies. Hence carbamylation of the samples before electrophoresis in antibody-containing gels gives rise to higher precipitates at given antigen and antibody concentrations. On the other hand, if a too intensive carbamylation takes place, blurred 'rockets' may be the results.

The described procedure is derived from series of experimental runs, in which the following variables were individually changed:

1) the concentration of potassium cyanate,

2) the reaction temperature,

3) the reaction time, and

4) the concentration of antisera in the gel.

The criteria for a succesful run were sharp and well defined anodical precipitates.

The sensitivity of the method for each of the three classes of immunoglobulins were chosen beforehand, but could be increased for other purposes (determination of immunoglobulins in other human secretions) by lowering the antibody concentrations or by concentrating the samples. The lower limits for quantitatively detectable immunoglobulins in terms of $\mathrm{kIU} / 1$ were $0.54,0.09$, and 2.04 for IgA, IgG and IgM respectively. The corresponding values in terms of $\mathrm{mg} / \mathrm{l}$ are 7.7 , 7.2, and 17.3, when the recommended converting factors for the WHO International Reference Preparation are used (5). The sensitivity of the variety of methods for determination of immunoglobulins in saliva are difficult to compare, mainly because of differences in standardization, and must be related to the precision of the individual assay. Generally, electroimmuno techniques $(6,7)$ seem to be more sensitive than radial immunodiffusion methods $(1,8)$. The precision of the method also seems satisfactory as the coefficients of variation are in the order of those 
found, when the much higher serum concentrations of the immunoglobulins are measured with the same technique.

In the present study, a serum standard was used for the determination of salivary immunoglobulins. In fact, secretory IgA standard would be more correct, but in using a pure secretory Ig-standard, there is a certain risk of inaccuracy, due to a possible denaturation of the protein. Furthermore, using an individually prepared secretory Ig-standard, this standard could not be related to any other known standard, which makes comparisons between the different laboratories impossible. Therefore, we chose a serum standard, calibrated in terms of the WHO Immunoglobulin Reference Preparation (9), which offers some possibilities for comparative studies. Furthermore, the serum standard could be stored at $-20^{\circ} \mathrm{C}$ for several years without loosing appreciable activity (10).

Determination of salivary immunoglobulins implies other difficulties, and the most important being the influence of salivary flow rate on the protein concentrations (11). To avoid this influence, most investigators had used 'maximal' secretory stimulation of parotid flow, which perhaps decreases individual dilution of saliva. Yet the application of a Curby cup on the orificium of Stenoni or the direct introduction of a catheter in the ductus undoubtedly also produces a stimulatory influence on the salivary flow rate. In this study we looked for a simple method for collection of saliva, which at the same time was acceptable for the children concerned. In collecting whole saliva, 'maximal' stimulation of salivary flow rate could not be provided, and therefore we decided to obtain the samples only by applying an insignificant stimulation with the plastic rubber.

Salivary $\operatorname{lgG}$ was found in most of the children but only in concentrations of one tenth of the values obtained for salivary IgA. The significance of IgG in saliva is uncertain, and presumably it is without any diagnostic value. Salivary IgG is postulated to be transmitted by passive diffusion from serum through the epithelium, although an additional contribution of local synthesis has been reported in a patient with IgA deficiency (11). In the present study salivary IgM was only found in a few children, which is in accordance with the results obtained by others (11). Generally, salivary IgM is only found in children with $\operatorname{IgA}$ deficiency $(12,13)$, and in these patients IgM is presumably acting as a compensatory secretory immunoglobulin, secreted and transmitted locallly.

The mean value for salivary IgA in unstimulated whole saliva in the 60 children concerned was estimated to 5.1 $\mathrm{kIU} / 1$. Savilahti (8) in stimulated parotid saliva found a mean salivary $\operatorname{IgA}$ of $2.1 \mathrm{kIU} / 1$ in 7 children. Oon \& Lee (14) in 44 adults found a mean salivary IgA of $1.9 \mathrm{kIU} / 1$ in unstimulated parotid saliva and a mean salivary IgA of $1.1 \mathrm{kIU} / 1$, when stimulated. These investigators have also used international standardization. Thus the amount of salivary IgA seems to be significantly higher in unstimulated whole saliva.

\section{References}

1. Khayam-Bashi, H., Slaughter, S. \& Blanken, R. M. (1976), Clin. Chim. Acta 66, 63-67.

2. Weeke, B. (1968), Scand. J. Clin. Lab. Invest. 21, 351-358.

3. Weeke, B. (1968), Scand. J. Clin. Lab. Invest. 22, 107-113.

4. Weeke, B. (1973), in: A Manual of Quantitative Immunoelectrophoresis (Axelsen, N. H., Krфll, J. \& Weeke, B., eds.), p. 15-35, Universitetsforlaget, Oslo.

5. Humphrey, J. H. \& Batty, I. (1974), Immunochemistry 11 , 759.

6. Claman, H. N., Merrill, D. A. \& Hartley, T. F. (1967), J. Allerg. Clin. Immunol. 40, 151-159.

7. Lopez, M., Tsu, T. \& Hyslop, N. (1969), Immunochemistry $6,513-526$.
8. Savilahti, E. (1973), Clin. Exp. Immiunol. 13, 395-406.

9. Rowe, D. S., Anderson, S. G. \& Grab, B. (1970), Bull. Wld. Hith. Org. 42, 535-538.

10. Weeke, B. (1972), in Protides of the Biological Fluids (Peeters, H. ed.) p. 547-550, Pergamon Press, Oxford.

11. Brandtzæg, P. (1971), Clin. Exp. Immunol. 8, 69-85.

12. Stocker, F., Ammann, P. \& Rossi, E. (1968), Arch. Dis. Childh. 43, 58.5-588.

13. Collinș-Williams, C., Kokubo, H. C., Lamenża, C., Nizami, R., Chiu, A. W., Lewis-McKinley, C., Comerford, T. A. \& Varga, E. A. Ann. Allerg. 30, 11-23.

14. Oon, C. H. \& Lee, J. (1972), J. Immun. Meth. 2, 45-52.
Dr. M. Blom Dëpt. Clin. Chem. CL 3011, Ringshospitalet Blegdamsveej 9 DK-2100 Copenhagen $\emptyset$ 